\title{
LYMPHO SARCOMA IN A LEOPARD - A CASE REPORT
}

\author{
K. Sujatha ${ }^{1}$, Ch. Srilatha ${ }^{2}$ and N. Sailaja ${ }^{3}$ \\ ${ }^{1,3}$ Assistant Professor; ${ }^{2}$ Associate Professor \& University Head; \\ Department of Pathology, College of Veterinary Science, Tirupati, \\ Andhra Pradesh 517502, India
}

plus web supplement of 1 page

The incidence of occurrence of tumors in zoo animals is sporadic in nature (Sivadas et al., 1968); malignant tumors are found to be more common than benign and most of the adult and aged animals succumbed to tumors (Rao, 2002). The incidence of lymphosarcoma in a Striped Hyaena was recorded by Nashiruddullah and Chakraborthy (2003) and a similar case has been reported herewith in a leopard.

A male leopard aged about eleven years belonging to S.V Zoological Park, Tirupati, was brought for postmortem examination. The animal was said to be ailing for ten days with dullness and anorexia. All visible mucous membranes were pale. Necropsy examination revealed free blood (approximately .51) and lemon-sized blood clots in the abdominal cavity. Severe subcutaneous haemorrhages were noticed at the inner side of scapula and the ventral side of abdominal region on the left. Submaxillary, prescapular precrural and mesenteric lymph nodes were enlarged 3-4 times than normal (Image $1^{w}$ ). Cut sections of the lymph nodes were firm and no demarcation between the cortex and medulla was noticed. The spleen was severely and diffusely enlarged (15 to 20 times) (Image $2^{\mathrm{w}}$ ) and was turgid and friable. The spleenic capsule was ruptured in some places with the pulp bulging out. The liver was slightly enlarged and firm in consistency with yellowish discolouration. Trachea and bronchi contained blood mixed with froth. The stomach and the intestines showed catarrhal changes and were empty. Bone marrow was soft and reddish with a little fatty tissue.

Microscopic examination of impression smears of bone marrow, spleen, and lymph nodes revealed the presence of significant number of monomorphic population of medium-sized lymphocytes with hyperchromatia of nucleus and occasional mitotic figures on Leishman's staining (Image $3^{\mathrm{w}}$ ). Represented tissue pieces preserved in $10 \%$ formal saline were processed in routine conventional method and stained by haematoxylin and eosion.

Histologically all the lymph nodes and spleen revealed broad sheets of lymphoblasts with anplastic changes (Image $4^{\mathrm{w}}$ ). The architecture of spleen and lymph nodes is lost because of massive infiltration of lymphoblasts in the white pulp and in lymphoid follicles. Periportal infiltration of lymphocytes was also noticed in the liver. Pulmonary changes included edema and congestion with hyperplacia of bronchial epithelium. Multifocal accumulation of lymphoblasts in mucosa and submucosa of stomach and intestines were seen. The clinical gross and histopathological findings of the present case are in accordance with previous reports (Baruah, 1983; Jubb \& Kennedy, 1985; Moultan, 1985) in the family Felidae.

\section{REFERENCES}

Baruah, M. (1983). Common diseases of wildlife in captivity with particular reference to northeastern region. Silver Jubilee Souvenir - Assam State Zoo, Guwhati, pp.32-35

" See Images in the web supplement at www.zoosprint.org

(C) Zoo Outreach Organisation; www.zoosprint.org Manuscript 1502; Received 10 January 2006; Revised received 14 June 2006; Finally accepted 19 August 2006; Date of publication 21 September 2006
Jubb, K.V.P. and C.P. Kennedy (1985). pp.107-108. A Text Book on Pathology of Domestic Animals. $3^{\text {rd }}$ ed. Academic Press. Inc, Orlando, Florida,

Moultan, E.J. (1985). pp. 156-160. Tumors in Domestic Animals. $2^{\text {nd }}$ ed. University of California Press, Berkeley.

Nashiruddullah, N. and A. Chakraborthy (2003). Spontaneous neoplasms in captive wild carnivores of the Asam State Zoo. Indian Journal of Veterinary Pathology 27(1): 39-41.

Rao, A.T. and L.N. Acharjyo (2002). Diseases of Wild Felids. $1^{\text {st }}$ ed. Repro Print (P) Ltd., Nayapalli, Bhubaneswar.

Sivadas, C.G., A. Rajan, M.K. Nair and K.M. Rmachandran (1968). Neoplasms of captive wild animals. Malaysian Veterinary Journal 4: 173-195.

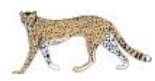

VET BRIEF ZOOS' PRINT JOURNAL 21(10): 2439-2440

\section{PREDATION BASED FATAL PERITONITIS IN A ROYAL BENGAL TIGER}

\section{J.L. Singh ${ }^{1}$, D. Swaroop ${ }^{2}$, M. Patel ${ }^{3}$ and L.K. Sanwal ${ }^{4}$}

${ }^{1}$ Assoc. Prof. Department of Clinical Medicine, ${ }^{2}$ Principal Scientist \& Head, Division of Medicine, I.V.R.I. Izatnagar, ${ }^{3}$ Assistant

Professor, Department of LPM, College of Veterinary and Animal

Sciences, G.B. Pant University of Agriculture \& Technology,

Pantnagar, U.S. Nagar, Uttaranchal

${ }^{4}$ Veterinary Officer, Nainital Zoo, Nainital, Uttaranchal plus web supplement of 1 page

Prey species of big cats range from small porcupines to the big Gaur depending on availability and circumstances. After hunting the animals, eating voraciously is a common phenomenon. While doing so, the predator may gulp both edible and non-edible parts of the kill, sometimes proving fatal. Among big cats, secondary peritonitis due to penetration by sharp foreign objects is a rare phenomenon when compared to infection (Rathore \& Khera, 1981). Among all types of foreign body peritonitis, prey-spine induced peritonitis is the least common. This paper describes a report on clinico-pathological aspect of squillpunctured secondary peritonitis.

An ailing Royal Bengal Tiger was rescued by the forest department during routine patrolling in the Jim Corbett National Park in July, 2003 and was transferred to the GB. Pant High Altitude Zoo, Nainital for therapeutic management. The Nainital Zoo Health Advisory Committee examined the tiger and took history of the incident. While recording history from the forest officials, it was learnt that the tiger had lameness in both of its hind limbs, weakness due to starvation and was smelling foul from a distance. On close inspection, it was found to have maggot wounds in different parts of its body. The ailing tiger's blood and peritoneal fluid were collected and detail haematological and cellular examination were done using standard methods. The tiger was treated with Ivermectin, Cefatoxime, Gentamycin, multi-vitamins, Ringer's lactate standard doses and C.T.C. dressing for a week.

Distant examination of the animal showed dullness and weakness along with presence of maggotted wound throughout the body (Image $\left.1^{\mathrm{w}}\right)$. On clinical examination the tiger showed sunken eye condition, praying mantis posture, hypothermia $\left(99^{\circ} \mathrm{F}\right)$, tucked up appearance of

${ }^{\mathrm{w}}$ see Images 1-3 in the web supplement at www.zoosprint.org

(C) Zoo Outreach Organisation; www.zoosprint.org Manuscript 1480; Received 12 December 2005; Finally accepted 21 May 2006; Date of publication 21 September 2006 